\title{
Soil- and waterborne Phytophthora species linked to recent outbreaks in Northern California restoration sites
}

\begin{abstract}
A review identifies several Phytophthora species found in California wildlands and discusses approaches for preventing and diagnosing the spread of these plant pathogens.
\end{abstract}

by Matteo Garbelotto, Susan J. Frankel and Bruno Scanu

\section{Abstract}

Many studies around the globe have identified plant production facilities as major sources of plant pathogens that may be released in the wild, with significant consequences for the health and integrity of natural ecosystems. Recently, a large number of soilborne and waterborne species belonging to the plant pathogenic genus Phytophthora have been identified for the first time in California native plant production facilities, including those focused on the production of plant stock used in ecological restoration efforts. Additionally, the same Phytophthora species present in production facilities have often been identified in failing restoration projects, further endangering plant species already threatened or endangered. To our knowledge, the identification of Phytophthora species in restoration areas and in plant production facilities that produce plant stock for restoration projects is a novel discovery that finds many land managers unprepared, due to a lack of previous experience with these pathogens. This review summarizes some of the key knowledge about the genus Phytophthora in general and lists some of the many soilborne and waterborne species recently recovered from some California restoration sites and plant production facilities.

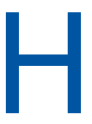

istorically, the release of Phytophthora species in the wild has resulted in massive die-offs of important native plant species, with cascading consequences on the health and productivity of affected ecosystems (Brasier et al. 2004; Hansen 2000; Jung 2009; Lowe 2000; Rizzo and Garbelotto 2003; Swiecki et al. 2003; Weste and Marks 1987). Once introduced, plant pathogens in general cannot be eradicated (Cunniffe et al. 2016; Garbelotto 2008), and costs associated with the spread and control of exotic pathogens and pests have been estimated to surpass $\$ 100$ billion per year for the United States alone (Pimentel et al. 2005). Thus, preventing the introduction of pathogens by using pathogen-free plant stock is the most cost-effective and responsible approach (Parnell et al. 2017).

In their extensive meta-analysis, Santini et al. (2013) identify the trade of live plants as the main pathway for the introduction of invasive forest diseases in Europe. Similarly, Jung et al. (2016) identified plant production facilities as a major source of
Phytophthora diseases are increasingly being found in California wildlands and parks, where they have caused large die-offs of native plant species. Shown here is lone manzanita (Arctostaphylos myrtifolia) in lone, California, killed by P. cinnamomi. 
Phytophthora inoculum that may be released in the wild. The best-known example of a Phytophthora species released in California natural environments from commercially produced plants is that of Phytophthora ramorum (Grünwald et al. 2012), but an equally important prior introduction associated with infested plant nurseries is that of Phytophthora lateralis, which affected Port Orford cedar in California and Oregon (Hansen et al. 2000).

Recently, Rooney-Latham and colleagues (RooneyLatham and Blomquist 2014; Rooney-Latham et al. 2015) identified at least two soilborne Phytophthora species, including one reported for the first time ever in the United States, as the cause of extensive mortality of two plant species recently employed in an extensive restoration project. Both species were also found in the production facilities that had supplied the plant stock, and both species have been shown, through greenhouse inoculation studies, to be aggressive pathogens on three important hosts present in the restoration areas (Sims et al. 2018). This discovery triggered multiple surveys of failed restoration projects and of the facilities that provided plants employed in such projects (Frankel et al. 2018). While soilborne and waterborne Phytophthoras have been found in commercial production of orchard and landscaping plants, to our knowledge this is the first reported case of Phytophthora species found in plants bound for native landscapes (Frankel et al. 2018; M. Garbelotto, unpublished results). Although Phytophthora species are known to be plentiful in commercial plant production facilities, their discovery in native plant production facilities is novel, and finds many land managers unprepared, due to a lack of previous experience with these pathogens.

Given that the research community has been focused on aerial Phytophthora species such as $P$. ramorum recently, this review summarizes some basic knowledge for soilborne and waterborne Phytophthora species, such as those recently recovered from restoration and disturbed sites in the San Francisco Bay Area in California. Even if we acknowledge that infected plants can often be asymptomatic (Bienapfl and Balci 2014; Jung et al. 2016; Migliorini et al. 2015), we hope this article may increase the awareness about this group of pathogens, possibly leading to their early detection in plant production facilities (Parke et al. 2014; Patel et al. 2016), before infected plants are outplanted in the wild.

\section{Introduction to the genus Phytophthora}

For decades, Phytophthora species have been erroneously lumped with the Fungi, but in order to fully understand their biology and ecology it is important to understand their correct taxonomic position. The genus Phytophthora belongs to the kingdom Straminipila (formerly Chromista), which also includes aquatic organisms such as diatoms and kelp (Dick 2001). The genus Phytophthora is part of the order Peronosporales: this order contains genera that are notable for having co-evolved with plant hosts mostly as plant pathogens, although some are pathogens of animals (Spies et al. 2016; Thines 2014). The four best-known genera are Peronospora, Plasmopara, Pythium and Phytophthora. Each has evolved distinct epidemiological strategies. While Peronospora and Plasmopara species (causal agents of plant diseases known as "downy mildews") mostly spread aerially, Pythium species are almost exclusively soilborne and waterborne. The genus Phytophthora stands between the two, and includes species that are soilborne and waterborne, or airborne, and some species with a mixed epidemiological strategy (Bourret et al. 2018; Oßwald et al. 2014).

Phytophthora propagules responsible for much of the known host-to-host spread are normally ovoid or pyriform in shape and are called sporangia (fig. 1A). Sporangia can be extremely variable in form and size and are normally produced alone or in clusters at the end of stalks. If sporangia can be easily detached from the stalks that bear them, the species may be aerially dispersed rather than just being soilborne and/or waterborne (Erwin and Ribeiro 1996).

Sporangia of all Phytophthora species, when mature, contain a variable number of motile, biflagellate zoospores (fig. 1B). Sporangia sometimes can germinate directly and infect a plant, or plants can be infected directly by hyphae growing in the soil. However, it is the zoospores that are mostly responsible for infection of plant tissue. Zoospores are normally attracted by chemical or electrical signals generated by the plant host (Carlile 1983) and require a film of water to "swim" and initiate the infection process. If there is no film of water or water dries out, zoospores can encyst and become dormant without losing viability. Infection by zoospores or by germinating sporangia can occur through stomatal openings, or an infection peg can rupture the plant cell wall and directly infect plant tissue (Erwin and Ribeiro 1996). The need for a film of water for zoospore-mediated infection to occur largely explains the direct relationship between increasing disease levels and increasing rainfall values.

Phytophthora species also produce spherical survival structures called chlamydospores (fig. 1C). The size of chlamydospores, the pattern and the abundance in which they are produced, and the thickness of their outer wall can often be diagnostic traits differentiating Phytophthora species. Chlamydospores can survive up to several years in adverse environmental conditions; they can also contaminate soil and water and be responsible for dispersal of the pathogen. In favorable conditions, chlamydospores can germinate directly or they can produce a sporangium. Like sporangia, chlamydospores are clonally produced and do not require mating.

Sexual structures produced by Phytophthora species after mating are called oospores and are produced by a single individual in homothallic species, or when 
two individuals bearing different mating types come into contact in heterothallic species. Exposure of heterothallic species to certain fungi or chemicals can also trigger the formation of oospores in the absence of mating (Pratt et al. 1972; Uchida and Aragaki 1980). Oospores are particularly thick walled and can also be regarded as long-term survival structures, often even more resilient to adverse conditions than chlamydospores (fig. 1D). Note that oospores of homothallic species will be genetically identical to the individual that produced them, because recombination between homologous chromosomes cannot generate variation, while oospores of heterothallic species will be genetically different from the two parents. Sexually generated variation may help the pathogen to adapt to novel environments or hosts.

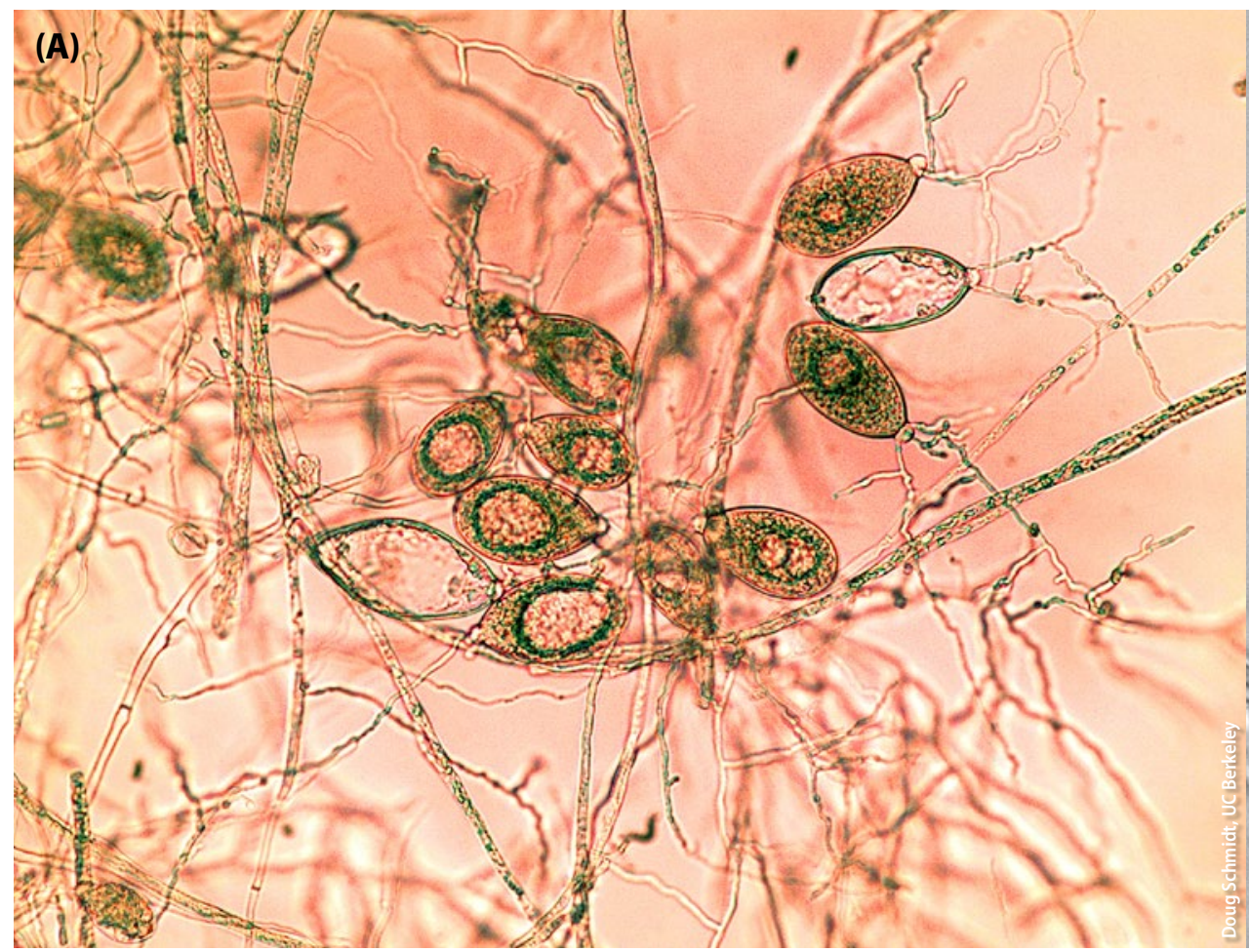

(B)

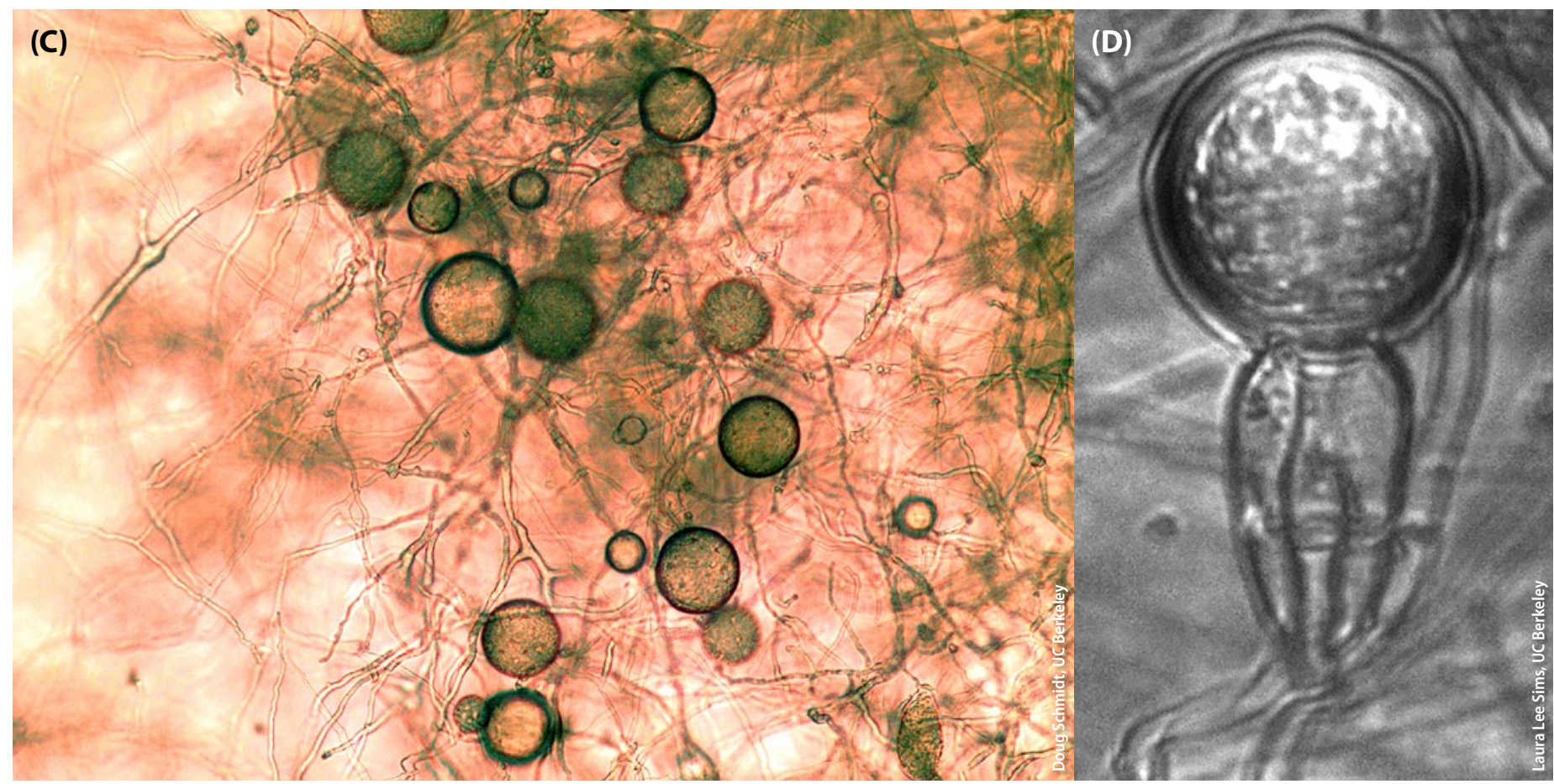

FIG. 1. Micrographs (300x magnification) of (A) sporangia of Phytophthora ramorum, (B) a zoospore exiting a sporangium of Phytophthora bilorbang, (C) chlamydospores of Phytophthora ramorum and (D) an oospore of Phytophthora alni subspecies uniformis. 
In addition to variation in morphological traits among different species, Phytophthora species have been differentiated based on the traits listed below. Some of these traits may have important implications for disease management and modeling (Erwin and Ribeiro 1996). For instance, one may assume that the release of a "cold-weather" Phytophthora species in a warm region may be relatively unsuccessful:

(1) Temperature preferences: that is, adaptation to warm, cool or cold environments (Cooke et al. 2000).

(2) Ability to infect a large number of unrelated hosts (generalists) versus ability to infect only closely related or a limited number of hosts (specialists) (Oßwald et al. 2014).

(3) Mode of reproduction. Individuals belonging to homothallic species can complete the sexual stage and produce oospores without mating. Two individuals carrying opposite mating types (namely A1 and A2) are needed instead by outcrossing, heterothallic species. It should be pointed out that sporangia are produced asexually both in homothallic and heterothallic species, so normally lack of sex does not interfere with spread of a species. Also, it seems plausible that homothallic species may survive in harsher climates (M. Garbelotto, unpublished data), thanks to the fact they can often easily produce oospores without the need for mating with a compatible strain.

(4) Range of soil pH preferred for growth (Kong et al. 2009).

(5) Evolutionary relationship or relatedness. Species belonging to the same clade (a clade is a group of closely related species that evolved from the same ancestor; based on Jung et al. [2017] there are at least 12 clades in the Phytophthora genus) often have similar biology and can hybridize (Brasier et al. 2004; Husson et al. 2015). Hybrids, however, may differ in host range and virulence from the parental species.

(6) Virulence. Some Phytophthora species may be defined as opportunistic, requiring a weakened host for infection or colonization, while other species are aggressive primary pathogens, leading to severe symptoms, impairment or mortality independent of host health status (Jung et al. 2011). This distinction is key in predicting the impact of emergent Phytophthora species; however, it is variable and the virulence of a species may change due to variation in the host or in the environment.

(7) Aerially spreading, or spreading through infested soil or water (Scanu and Webber 2016).

\section{Soilborne and waterborne versus aerial species}

The part of the plant that a Phytophthora species infects (roots, foliage or stem) drives many aspects of disease epidemiology. It is unclear what makes a Phytophthora species well adapted to be either airborne and primarily infect aerial parts of plants, or to be soilborne or waterborne with infections primarily limited to the roots and root collars. In the second case, aboveground symptoms are not caused directly by infection but are a consequence of root mortality and of girdling of the root collar (fig. 2). It should be noted that the distinction between airborne and soilborne or waterborne species is not always clear-cut. In general, we define as airborne those species that spread through
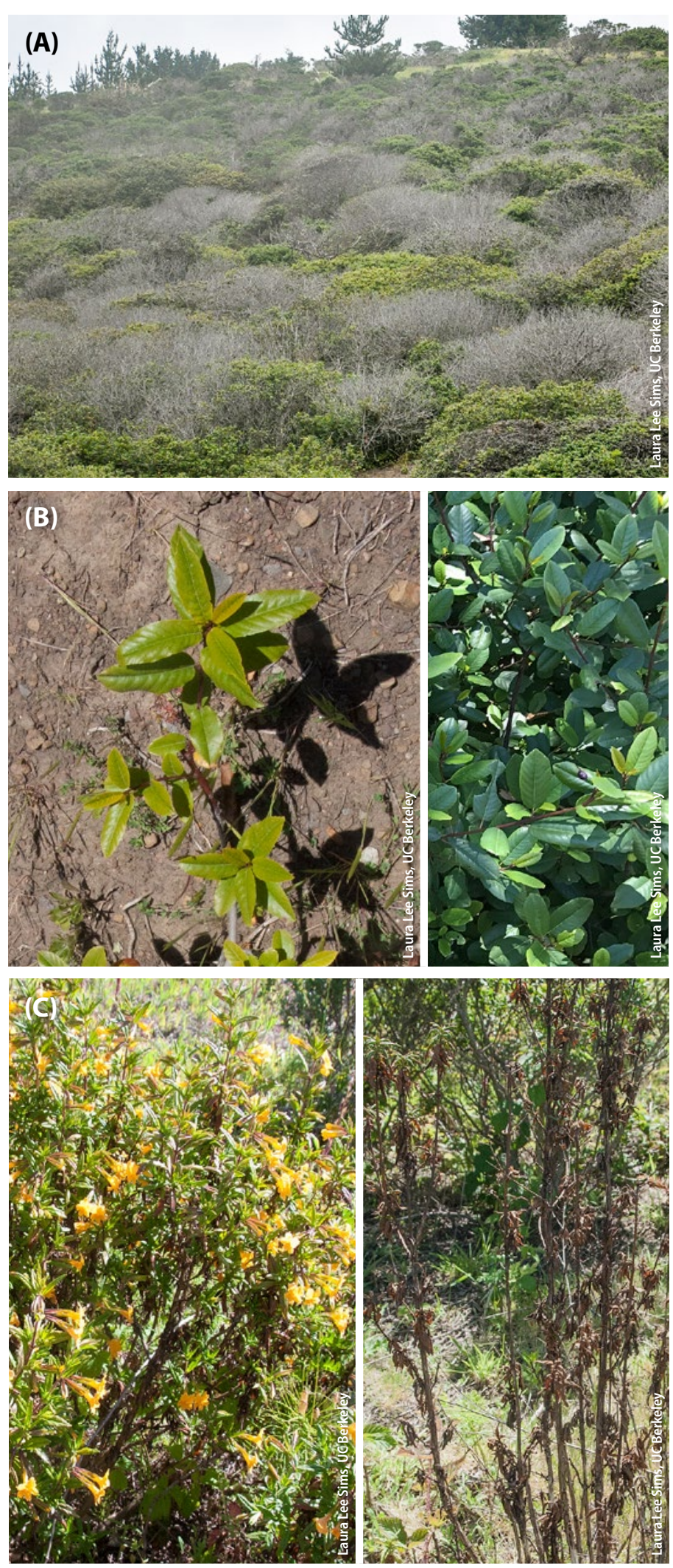

FIG. 2. Visible symptoms caused by root and root collar infection by soilborne and waterborne Phytophthora species. (A) Coffeeberry (Frangula californica) in San Mateo County infected by Phytophthora multivora; (B) coffeeberry outplanted in Marin County infected by Phytophthora megasperma on the left, and healthy coffeeberry on the right; and (C) healthy sticky monkey flower (Diplacus aurantiacus) on the left, and plants infected by Phytophthora megasperma on the right. 
airborne propagules, while the soilborne and waterborne category includes species that mostly spread through soil and water contaminated by propagules. To be more precise, some species within the soilborne and waterborne group appear to be better adapted to live in water (e.g., lakes, streams, ponds), while others may preferentially be found in matrical soil water. However, we believe this difference to be often debatable and have decided to group together soilborne and waterborne species in the same group. Table 1 compares a few important traits between soilborne and waterborne and airborne species.

TABLE 1. A quick comparison of a few traits of soilborne/waterborne and airborne Phytophthora species

Soilborne and waterborne
They infest soil and water, and mostly infect
roots and root collar. They can also infect
aerial portions of plants through infested
tools or splash of soil or water particles
(Madden et al. 1992; Scanu and Webber 2016;
Trione and Roth 1957).
They can survive for relatively long periods
in soil or potting media. Survival may be
independent of plant debris present in the
soil (Vettraino et al. 2010), while sporulation
appears to be linked to the presence of roots
or root fragments embedded in the soil (Jung
et al. 2013).

Production of chlamydospores, or oospores or stromata-like hyphal aggregations (masses of vegetative structures) may be necessary for long-term survival in soil (Crone et al. 2013).

Sporangia can be caducous or not caducous (Erwin and Ribeiro 1996).

They can survive in soil but are not extremely long-lived (Fichtner et al. 2007) and are less competitive than soilborne and waterborne species (Eyre et al. 2013). Conversely, survival in inert potting media can be extensive (Shishkoff 2007).

Production of chlamydospores, or oospores or stromata-like hyphal aggregations (masses of vegetative structures) may be necessary for long-term survival in soil (Crone et al. 2013).

Sporangia are almost always caducous (i.e., deciduous) (Erwin and Ribeiro 1996). less abundant in sandy, well-drained soils (Cook and Papendick 1972); their frequency increases as rainfall and temperature increase (Thompson et al. 2014); and high levels of soil infestation are associated with soils that are poor in organic matter (Weste and Marks 1987), as in the case of serpentine soils (Shearer and Crane 2011). Furthermore, disease development appears to be more marked in those climates that alternate between wet and dry periods, for example, regions characterized by a Mediterranean climate (Burgess et al. 2016). The reasons behind marked disease severity in areas with Mediterranean climate may be twofold. First, wet-dry cycles maximize the frequency and the duration of periods in which soil is wet but not saturated at field capacity; in fact, anaerobiosis in saturated soils actually depresses sporulation by Phytophthoras (Nesbitt et al. 1979). Second, plants infected during wet periods may then become more susceptible to colonization by Phytophthoras due to the stress induced by prolonged periods of drought (DesprezLoustau et al. 2006).

\section{Establishment and spread of exotic species}

A consequence of being soilborne or waterborne is an extremely patchy distribution at the landscape level. However, the distribution of soilborne or waterborne Phytophthora species can be further expanded through various human-related mechanisms, including planting of infected plants and movement of soil along roads or paths (Krull et al. 2013; Ristaino and Gumpertz 2000). Additionally, once introduced in a site, propagules of these pathogens will move on their own following gravity and movement of water in waterways and in underground water tables (Maurel et al. 2001). When humans are not directly involved in their spread, these pathogens often appear to move more easily downhill than uphill. Downhill spread can be significant because it occurs via both root contacts and downward movement of infested water or contaminated soil. Uphill movement, by contrast, is usually more limited, because it relies almost exclusively on root contacts.

There are some commonalities among all soilborne and waterborne species: They tend to be more abundant in soils with a loamy to clay structure and
Major pathways for the initial primary introduction of exotic soilborne and waterborne Phytophthora species in a new region include the use of infected plant material or of infested soil (Liebhold et al. 2012; Parke et al. 2014). Phytophthora inoculum (e.g., infectious propagules) may be present either in infected plant tissue, in the soil plants have been grown in, or in both (Jung et al. 2016). Once introduced in a new site, secondary spread up to a few meters per year can be the result of root-to-root infection or of infection of roots by hyphae, and of movement of infectious or survival structures (sporangia, chlamydospores and oospores) through splash (Ristaino and Gumpertz 2000), or of the movement of insects or small animals that may carry Phytophthora propagules on their bodies. Longerrange spread, up to tens or even hundreds of kilometers per year, can occur through soil movement due to vehicular traffic or to animal movement, and through the movement of infested water.

Spread through infested water may occur at different spatial scales: a few meters when dealing with matrical water (i.e., water present among soil particles), tens or hundreds of meters for runoff water, hundreds or even thousands of meters for infested underground water tables (Hayden et al. 2013), and even longer distances for infested water carried in streams and rivers as evidenced for the spread of $P$. lateralis in southern Oregon and Northern California (Hansen et al. 2000). Infested water can also be moved by helicopter or trucks used for firefighting or for road dust abatement. Spread at the landscape level is thus affected by abundance of roads and streams, by intensity of human activities, by topography (with draws and depressions being more conducive to spread), by abundance of 
favorable sites (clay soils, lower organic content) and by densities of animals and, especially, of susceptible hosts. Abundance of snails and ants may also contribute to increase disease severity in a site (El-Hamalawi and Menge 1996).

Increasing host diversity in a site may have diametrically different effects on disease spread rate and disease severity. When the percentage of infectious hosts increases (note that some hosts may be susceptible but not infectious), so do disease spread rate and disease severity. This is, for instance, the case of some Lupinus species present in woodlands infested by P. cinnamomi in Spain (Serrano et al. 2010). Conversely, when increased host diversity leads to a decrease of percentage of the more infectious hosts, an effect called "inoculum dilution" leads to decreased spread rates and disease severity (Haas et al. 2011).

\section{Prevention and diagnostics of Phytophthora species}

The most effective control of soilborne or waterborne Phytophthoras relies either on the prevention of their introduction or on slowing their further spread, once introduced. Prevention of primary introductions can be achieved by properly testing plant material to be outplanted and by using stock produced in facilities that observe best management practices (BMPs) aimed at limiting establishment of these soilborne pathogens in soil, pots and water systems as well as plants (Parke and Grünwald 2012). Recently, BMPs aimed at reducing risk of infestation have become available (see Sims et al. 2018 or www.suddenoakdeath. org/wp-content/uploads/2016/04/Restoration.Nsy_. Guidelines.final_.092216.pdf and http://ucanr.edu/ phytophthorabmps).

Notwithstanding the use of material produced in facilities adhering to such BMPs, it has been repeatedly advised to place all new plant material in a quarantined area for several weeks and to observe it for the onset of symptoms (Alexander and Lee 2010). In the absence of a certificate indicating the production facility is free of Phytophthora species (Brasier 2008), a direct inspection of plants to be purchased needs to be performed, including observations of the health status of root systems.

Four different approaches may be utilized for direct testing of these substrates:

(1) Baiting. Plant material (symptomatic and asymptomatic), root and soil samples can be baited by submerging the sample in water and floating baits comprised of susceptible plant parts such as leaves and fruits. Baiting must be done under aerobic conditions assured by mixing the correct amounts of plant material or soil and water (see Erwin and Ribeiro 1996), but protocols vary greatly with regards to specific baiting protocols (Jung et al. 1996; Scanu et al. 2013). Different baits (e.g., consisting of different plant species or of different plant parts) may not be equally effective when trying to detect different Phytophthora species (Erwin and Ribeiro 1996). In some cases, drying the soil before baiting is recommended (Erwin and Ribeiro 1996). One advantage of baiting is that precise knowledge of the exact portion of the plant or the specific soil particles that may contain viable Phytophthora infection is not needed; for this reason, baiting is one of the preferred diagnostic approaches when surveying large facilities, soil and wildland waterways. However, for unknown reasons, some species are difficult to detect by baiting and thus negative baiting results can represent false negatives. Furthermore, baiting requires experience, particularly in the identification of the agent causing the symptoms on the bait, which can be done by direct culturing or by the use of molecular approaches on symptomatic tissue (see 2 and 3 below).

(2) Direct isolation from symptomatic (or asymptomatic) plant tissue using Phytophthora selective media (Jeffers and Martin 1986; Scanu et al. 2014). There are a few drawbacks of direct isolation: (a) one needs to sample a portion of the plant where the pathogen is viable and viability may be dependent on season and/or phenological state of the host plant; and (b) some species may have almost identical morphology and therefore are difficult to identify correctly without molecular testing. The most significant drawback of this approach is that sampling requires destructively excising a portion of the plant, and often that requires destructively manipulating plants to identify symptomatic portions to be plated. False negatives for both direct isolation and baiting techniques can occur in the case of species that are not easily culturable, or due to the presence of secondary microorganisms preventing Phytophthoras from growing axenically.

(3) Molecular identification techniques are based on the detection of specific sequences of nucleic acids (DNA, RNA) (Martin et al. 2012; Prigigallo et al. 2015). Molecular approaches are not dependent on the viability of the pathogen but do require that the correct portion of an infected plant be processed. Additionally, there are risks of false positives due to either lab contamination or to a lack of specificity of the assay detection probes, caused either by the existence of undiscovered closely related species or by poor probe design. False negatives are commonly caused by poor processing or by the presence of inhibitors, whose concentration in tissues or substrate may vary depending on time of year and material sampled.

The high sensitivity of molecular approaches thus can be regarded both as a benefit and a drawback. A benefit because it allows the detection of relatively young incipient infections or infections in remission characterized by a low amount of pathogen DNA (Hayden et al. 2004). A drawback because results with such approaches may not be informative as to the viability of the pathogen, due to the fact that unviable dead cells of the target organism may also be detected (Chimento et al. 2011). 
Molecular identification assays normally are based on one of two approaches: (a) Results may be positive or negative and based on the success or failure of assays specifically designed to target one or a few species. Or (b) Results may be based on the homology (e.g., similarity) of DNA sequences of so-called barcode genetic loci. The two most common barcode loci for Phytophthora species identification are the nuclear internal transcribed spacer (ITS) and the mitochondrial cytochrome oxidase (COX) (Cooke et al. 2000; Martin et al. 2014). In general, homology has to be $98 \%$ or higher between a published sequence and the sequence of an unknown sample to identify the unknown. Most conspecific genotypes have a DNA homology of $99 \%$ to $100 \%$. Sequences are published in several databases, but the most commonly used one remains GenBank (www. ncbi.nlm.nih.gov/genbank/). One caveat: The robustness of species identification based on DNA homology depends on ensuring the published sequence is associated with a correctly identified species.

(4) Immunological techniques are based on the detection of specific antibodies to proteins or other molecules produced by a pathogen species. These techniques, including the enzyme-linked immunosorbent assay (ELISA) and lateral flow device (LFD), showed higher diagnostic sensitivities than that of culturebased morphological identification, which can be influenced by environmental conditions (Lane et al. 2010). ELISA tests are generally inexpensive and relatively easy to perform, which makes them suitable for largescale prescreening. On the contrary, LFD tests are more expensive and are not suitable for large-scale testing. Their strength is that they are rapid and robust, and
The undersides of these petri dishes filled with Phytophthora-selective growth medium show Phytophthora colonies growing out of baits. can be used outside the laboratory (Lane et al. 2010). A general limitation of these techniques is that the antibodies used for ELISA and LFD rarely are speciesspecific and often cross-react with several Pythium species (Timmer et al. 1993).

Control or mitigation of extant Phytophthora infestations deserves its own review, but an excellent synthesis of approaches has been provided by Hayden et al. (2013), and we refer the reader to such a review.

\section{Phytophthora species possibly detected in restoration sites}

As of the summer of 2017, at least 25 soilborne Phytophthora species have been recovered in restoration sites near natural ecosystems or in parks in the greater San Francisco Bay Area in California. Eight species are well known, eight are closely related and belong to Clade 6, and nine represent new putative hybrid species (see supporting table S1 online, http://ucanr.edu/u. $\mathrm{cfm}$ ? id=215, for a partial list). All identifications were done both on cultures in vitro, and were based in part on morphology and in part on the homology of DNA sequences between published sequences and sequences of newly obtained isolates at the species-specific loci ITS and/or COX (Martin et al. 2012). Identification of novel Phytophthora species, their hosts or substrates and the California counties in which these species were found is still being completed, and, as a result, the information provided in table S1 should be taken as provisional and subject to change. Contributors of unpublished data are acknowledged in the acknowledgements section at the end of this review.

Please note that as this review is being written, more Phytophthora species are being discovered in California wildlands and parks; however, these species are not included here because they have not been shared yet by their identifiers. Also, note that the distribution information in this review is simply limited to the few areas that have already been surveyed. Hence, the actual distribution of the Phytophthora species included in this paper may be much larger than that reported here and may increase as more surveys are completed. Additionally, the taxonomy of these species is in flux, and thus their species designation may change in the future.

A provisional and partial list of soilborne species isolated in sites in Northern California as of the summer of 2017 includes, in alphabetical order, P. bilorbang, P. cactorum, P. chlamydospora, P. cinnamomi, $P$. citricola, $P$. crassamura, $P$. cryptogea, $P$. erythroseptica, $P$. gonapodyides, P. inundata, P. 'kelmania', P. lacustris, $P$. megasperma, $P$. plurivora, $P$. quercetorum, $P$. riparia and $P$. tentaculata. Nine hybrid species were also identified, but their precise diagnosis is yet to be completed, so we prefer to omit them. Table S1 provides a comparative analysis of the species listed in this review, for a range of important traits. 


\section{Phytophthora diseases are no longer limited to the ornamental plant production industry or to agriculture, but are also emerging as a complex issue in wildlands.}

In conclusion, Phytophthora diseases are no longer limited to the ornamental plant production industry or to agriculture but are also emerging as a complex issue in native plant production and deployment. These diseases are emerging not only in association with inadvertent casual introductions, or due to the proximity of wildlands to agricultural settings, but also, unexpectedly, in association with infested plant production facilities providing stock for restoration projects and thus with restoration projects themselves. The problem is compounded by several issues, including (1) our inability to properly sample plant stock and the need for new sampling approaches (see Swiecki et al. 2018, page 217 in this issue), (2) the realization that Phytophthora species are in a continuum ranging from impossible to culture to easily culturable, (3) the fact that geographic distribution and the host ranges of Phytophthora species are not clearly known and are constantly changing, (4) the discovery of novel species at a faster pace than ever before and, finally, (5) reports that species forced to comingle in production facilities and in infested wildlands may generate new hybrid entities.

Early detection and understanding that there is a Phytophthora problem in Northern California remain key tools for mitigating and preventing further infestations. This will require that the scientific community continue raising awareness about this emerging problem and familiarizing stakeholders with details of some of the Phytophthora species that are increasingly being found in California wildlands. CA

M. Garbelotto is UC Cooperative Extension Specialist and Adjunct Professor, Department of Environmental Science, Policy and Management, University of California, Berkeley; S.J. Frankel is Forest Pathologist, U.S. Forest Service, Pacific Southwest Research Station, Albany, CA; and B. Scanu is Research Scientist and Lecturer, Dipartimento di Agraria, Sezione di Patologia Vegetale ed Entomologia (SPaVE), Università degli Studi di Sassari, Sassari, Italy.

Funding for this review was provided by the San Francisco Public Utilities Commission and the assistance of Mia Ingolia, Jessica Appel and Greg Lyman is appreciated. Data on Phytophthora species identified in California were kindly provided by Tedmund Swiecki and Elizabeth Bernhardt, Phytosphere Research; Laura Lee Sims and Matteo Garbelotto, UC Berkeley; Tyler Bourret and David M. Rizzo, UC Davis; and Suzanne RooneyLatham and Cheryl Blomquist, California Department of Food and Agriculture.

\section{References}

Alexander J, Lee CA. 2010. Les sons learned from a decade of sudden oak death in California: Evaluating local management Environ Manage 46:315-28.

Bienapfl JC, Balci Y. 2014. Movement of Phytophthora spp. in Maryland's nursery trade. Plant Dis 98(1):134-44.

Bourret TB, Choudhury RA, Mehl HK, et al. 2018. Multiple origins of downy mildews and mito-nuclear discordance within the paraphyletic genus Phytophthora. PLOS ONE 13(3):e0192502.

Brasier CM. 2008. The biosecurity threat to the UK and global environment from international trade in plants. Plant Path 57(5):792-808.

Brasier CM, Kirk SA, Delcan J, et al. 2004. Phytophthora alni sp. nov. and its variants: Designation of emerging heteroploid hybrid pathogens spreading on Alnus trees. Mycol Res 108:1172-84.
Burgess TI, Scott JK, McDougall $\mathrm{KL}$, et al. 2016. Current and projected global distribution of Phytophthora cinnamomi, one of the world's worst plant pathogens. Glob Change Biol 23(4):1661-74.

Carlile MJ.1983. Motility, taxis, and tropism in Phytophthora. In: Erwin DC, Bartnicki-Garcia S, Tsao PH (eds.). Phytophthora: Its Biology, Taxonomy, Ecology and Pathology. St. Paul, MN: American Phytopathological Society. p 95-107.

Chimento A, Cacciola S, Garbelotto M. 2011. Detection of mRNA by reverse-transcription PCR as an indicator of viability in Phytophthora ramorum. For Path 42:14-21. doi: 10.1111/ j.1439-0329.2011.00717.x

Cook RJ, Papendick RI. 1972. Influence of water potential of soils and plants on root disease. Ann Rev Phytopathol 10:349-74.

Cooke DE, Drenth A, Duncan JM, et al. 2000. A molecular phylogeny of Phytophthora and related oomycetes. Fungal Genet Biol 30(1):17-32.
Crone M, McComb JA, O'Brien PA, et al. 2013. Survival of Phytophthora cinnamomi as oospores, stromata, and thickwalled chlamydospores in roots of symptomatic and asymptomatic annual and herbaceous perennial plant species. Fungal Biol 117(2):112-23.

Cunniffe NJ, Cobb RC, Meentemeyer RK, et al. 2016. Modeling when, where, and how to manage a forest epidemic motivated by sudden oak death in California. Proc Natl Acad Sci 113(20):5640-5

Desprez-Loustau ML, Marçais B, Nageleisen LM, et al. 2006. Interactive effects of drought and pathogens in forest trees. Ann For Sci 63:597-612.

Dick MW. 2001. Straminipilous Fungi: Systematics of the Peronosporomycetes Including Accounts of the Marine Straminipilous Protists, the Plasmodiophorids and Similar Organisms. Dordrecht, Boston: Kluwer Academic Publishers.
El Hamalawi ZA, Menge JA. 1996. The role of snails and ants in transmitting the avocado stem canker pathogen, Phy tophthora citricola. J Am Soc Hortic Sci 121(5):973-7.

Erwin CD, Ribeiro OK. 1996. Phytophthora Diseases Worldwide. St. Paul, MN: American Phytopathological Society Press. $562 \mathrm{p}$

Eyre CA, Kozanitas M, Garbelotto M. 2013. Population dynamics of aerial and terrestria populations of Phytophthora ramorum in a California forest under different climatic conditions. Phytopathology 103(11):1141-52.

Farr DF, Rossman AY. 2018 Fungal Databases, U.S. National Fungus Collections, ARS, USDA. https://nt.ars-grin.gov/fungaldatabases/ (accessed Feb. 9, 2018).

Fichtner EJ, Lynch SC, Rizzo DM. 2007. Detection, distribution, sporulation, and surviva of Phytophthora ramorum in a California redwood-tanoak forest soil. Phytopathology 97(10):1366-75.
Frankel S, Alexander J, Benner D, Shor A. 2018. Coordinated response to inadvertent introductions of pathogens to California restoration areas. Calif Agr 72(4):205-7. doi:10.3733/ ca.2018a0035

Garbelotto M. 2008. Molecular analysis to study invasions by forest pathogens: Examples from Mediterranean ecosystems. Phytopathol Mediterr 47:183-203.

Grünwald NJ, Garbelotto M Goss EM, et al. 2012. Emergence of the sudden oak death pathogen Phytophthora ramorum. Trends Microbiol 20:131-8. Haas SE, Hooten MB, Rizzo DM et al. 2011. Forest species diversity reduces disease risk in a generalist plant pathogen invasion. Ecol Lett 14:1108-16. Hansen EM, Goheen DJ, Jules ES, et al. 2000. Managing Portorford-cedar and the introduced pathogen Phytophthora lateralis. Plant Dis 84(1). 
Hayden KJ, Hardy GESJ, Garbelotto M. 2013. Oomycetes diseases. In: Gonthier P, Nicolotti $G$ (eds.). Infectious Forests Diseases. London: CAB Publishing. p 518-45.

Hayden, KJ, Rizzo D, Tse J, Garbelotto M. 2004 Detection and quantification of Phytophthora ramorum from California forests using a real-time polymerase chain reaction assay. Phytopathology 94:1075-83.

Husson C, Aguayo J, Revellin C, et al. 2015. Evidence for homoploid speciation in Phytophthora alni supports taxonomic reclassification in this species complex. Fungal Genet Biol 77:12-21.

Jeffers SN, Martin SB. 1986 Comparison of two media selective for Phytophthora and Pythium species. Plant Dis 70:1038-43.

Jung T. 2009. Beech decline in Central Europe driven by the interaction between

Phytophthora infections and climatic extremes. Forest Pathol 39:73-94.

Jung T, Blaschke H, Neumann P. 1996. Isolation, identification and pathogenicity of Phytophthora species from declining oak stands. Eur J For Path 26:253-72.

Jung T, Burgess TI. 2009. Reevaluation of Phytophthora citricola isolates from multiple woody hosts in Europe and North America reveals a new species, Phytophthora plurivora sp. nov. Persoonia 22:95-110. Jung T, Colquhoun IJ, Hardy GESJ. 2013. New insights into the survival strategy of the invasive soilborne pathogen Phytophthora cinnamomi in different natural ecosystems in Western Australia. Forest Path 43(4):266-88.

Jung T, Jung MH, Cacciola SO, et al. 2017. Multiple new cryptic pathogenic Phytophthora species from Fagaceae forests in Austria, Italy and Portugal. IMA Fungus 8(2):219-244.

Jung T, Orlikowski L, Henricot $B$, et al. 2016. Widespread Phytophthora infestations in European nurseries put forest. semi-natural and horticultura ecosystems at high risk of Phytophthora diseases. Forest Path 46:134-63.

Jung T, Stukely MJC, Hardy GESJ, et al. 2011. Multiple new Phytophthora species from ITS Clade 6 associated with natura ecosystems in Australia: Evolutionary and ecological implications. Persoonia 26:13-39.
Kong P, Moorman GW, Lea-Cox JD, et al. 2009. Zoosporic tolerance to $\mathrm{pH}$ stress and its implications for Phytophthora species in aquatic ecosystems. Appl Environ Microb 75(13):4307-14.

Krull CR, Waipara NW, Choquenot $\mathrm{D}$, et al. 2013. Absence of evidence is not evidence of absence: Feral pigs as vectors of soil-borne pathogens. Austral Ecol 38(5):534-42.

Lane CR, Hobden E, Walker L, et al. 2010. Evaluation of a rapid diagnostic field test kit for identification of species, including $P$. ramorum and $P$. kernoviae at the point of inspection. Plant Patho 100(2):143-9.

Liebhold AM, Brockerhoff EG, Garrett L, et al. 2012. Live plant imports: The major pathway for forest insect and pathogen invasions of the US. Front Ecol Environ 10:135-43.

Lowe SJ, Browne M, Boudjelas S. 2000. 100 of the World's Worst Invasive Alien Species. Auckland, New Zealand: ISSG Pub.

Madden, LV, Wilson LL, Yang X, Ellis MA. 1992. Splash dispersal of Colletotrichum acutatum and Phytophthora cactorum by short-duration simulated rains. Plant Pathol 41:427-36.

Martin FN, Abad ZG, Balci Y, et al. 2012. Identification and detection of Phytophthora: Reviewing our progress, identifying our needs. Plant Dis 96:1080-103.

Martin FN, Blair JE, Coffey MD. 2014. A combined mitochondrial and nuclear multilocus phylogeny of the genus Phytophthora. Fungal Genet Biol 66:19-32

Maurel M, Robin C, Capron G, et al. 2001. Effects of root damage associated with Phytophthora cinnamomi on water relations, biomass accumulation, mineral nutrition and vulnerability to water deficit of five oak and chestnut species. For Pathol 31:353-69.

Migliorini D, Ghelardini L, Tondini $E$, et al. 2015. The potential of symptomless potted plants for carrying invasive soilborne plant pathogens. Divers Distrib 21(10):1218-29.

Nesbitt HJ, Malajczuk N, Glenn AR. 1979. Effect of soil moisture and temperature on the survival in soil of Phytophthora cinnamoni Rands. Soil Biol Biochem 11:137-40.

Oßwald W, Fleischmann F, Rigling D, et al. 2014. Strategies of attack and defence in woody plant-Phytophthora interactions. For Pathol 44:169-90.

Parke JL, Grünwald NJ. 2012. A systems approach for management of pests and pathogens of nursery crops. Plant Dis 96:1236-44.
Parke JL, Knaus BJ, Fieland VJ, et al. 2014. Phytophthora community structure analyse in Oregon nurseries inform systems approaches to disease management. Phytopathology 104:1052-62.

Parnell $S$, van den Bosch F, Gottwald T, Gilligan CA. 2017. Surveillance to inform control of emerging plant diseases: An epidemiological perspective. Annu Rev Phytopathol 55(1).

Pimentel D, Zuniga R, Morrison D. 2005. Update on the environmental and economic costs associated with alien-invasive species in the United States. Ecol Econ 52(3):273-88.

Pratt BH, Sedgley JH, Heather WA, Shepherd CJ. 1972 Oospore production in Phytophthora cinnamomi in the presence of Trichoderma koningii. Australian J Biol Sci 25(4):861-4.

Prigigallo M, Mosca S, Cacciola S, et al. 2015. Molecular analysis of Phytophthora diversity in nursery-grown ornamental and fruit plants. Plant Pathol 64:1308-19.

Ristaino JB, Gumpertz ML. 2000. New frontiers in the study of dispersal and spatial analysis of epidemics caused by species in the genus Phytophthora. Annu Rev Phytopathol 38:541-76.

Rizzo DM, Garbelotto M. 2003. Sudden oak death: Endangering California and Oregon forest ecosystems. Frontiers in Ecol Environ 1(4):197-204.

Rizzo DM, Garbelotto M, Hansen EM. 2005. Phytophthora ramorum: Integrative research and management of an emerging pathogen in California and Oregon forests. Annu Rev Phytopathol 43:309-35.

Rooney-Latham S, Blomquist CL. 2014. First report of root and stem rot caused by Phytophthora tentaculata on Mimulus aurantiacus in North America. Plant Dis 98(7):996.

Rooney-Latham S, Blomquist CL, Swiecki TJ, et al. 2015. First detection in the US: New plant pathogen, Phytophthora tentaculata, in native plant nurseries and restoration sites in California. Native Plants J 16(1):23-7.

Santini A, Ghelardini C, De Pace $M$, et al. 2013. Biogeographical patterns and determinants of invasion by forest pathogens in Europe. New Phytologist 197:238-50. doi:10.111 1/j.1469-8137.2012.04364

Scanu B, Linaldeddu BT, Franceschini $A$, et al. 2013. Occurrence of Phytophthora cinnamomi in cork oak forests in Italy. For Pathol 43:340-3.

Scanu B, Linaldeddu BT, Pérez Sierra A, et al. 2014. Phytophthora ilicis as a leaf and stem pathogen of Ilex aquifolium in Mediterranean islands. Phytopathol Mediterr 53:480-90.

Scanu B, Webber JF. 2016.

Dieback and mortality of

Nothofagus in Britain: Ecology, pathogenicity and sporulation potential of the causal agent Phytophthora pseudosyringae. Plant Pathol 65:26-36.

Serrano MS, Fernández-Rebollo P, De Vita P, et al. 2010. Lupinus luteus, a new host of Phytophthora cinnamomi in Spanish oak-rangeland ecosystems. Eur Plant Pathol 128(2):149-52.

Shearer BL, Crane CE. 2011. Habitat suitability of soils from a topographic gradient across the Fitzgerald River National Park for invasion by Phytophthora cinnamomi. Australas Plant Pathol 40:168-79.

Shishkoff N. 2007. Persistence of Phytophthora ramorum in soil mix and roots of nursery ornamentals. Plant Dis 91(10):1245-9.

Sims L, Garbelotto M. 2018. Susceptibility to the rare Phytophthora tentaculata and to the widespread Phytophthora cactorum is consistent with host ecology and history. Forest Pathol. doi:10.1111/efp.12446 Sims L, Tjosvold S, Chambers D, Garbelotto M. 2018. Control of Phytophthora species in plant stock for habitat restoration through best management practices. Plant Pathol. doi:10.1111/ppa.12933

Spies CFJ, Grooters AM, Lévesque CA, et al. 2016. Molecular phylogeny and taxonomy of Lagenidium-like oomycetes pathogenic to mammals. Fungal Biol 120(8):931-47.

Swiecki TJ, Bernhardt EA, Garbelotto M. 2003. First report of root and crown rot caused by Phytophthora cinnamomi affecting native stands of Arctostaphylos myrtifolia and A. viscida in California. Plant Dis 87:1395.

Swiecki TJ, Quinn M, Sims L, et al. 2018. Three new Phytophthora detection methods, including training dogs to sniff out the pathogen, prove reliable. Calif Agr 72(4):217-25.

Thines M. 2014. Phylogeny and evolution of plant pathogenic oomycetes-a global overview. 